\title{
BROWNFIELD DILEMMAS IN THE TRANSFORMATION OF POST-COMMUNIST CITIES: A CASE STUDY OF OSTRAVA, CZECH REPUBLIC
}

\author{
Barbora Duží*, Jiří Jakubínský \\ Global Change Research Centre AS CR, Brno, Czech Republic
}

\begin{abstract}
The main purpose of the paper is to analyse the procedures of urban brownfield solutions, with a focus on the environmental and cultural-historical aspects. The paper explores the dilemmas of brownfield regeneration and redevelopment. These processes are placed in the wider perspective of multi - transformation processes of post-communist cities. We compared two former industrial zones - Karolina and the Lower Area of Vítkovice in the city of Ostrava - where we illustrated the key factors influencing their transformation. These case studies point to a unique example of urban industrial brownfields concentrated within the area around the city centre, surrounded by residential zones. These brownfields also reveal the scope of the problem, as they are connected not only with the urban structure, but also with environmental, economic, social and cultural aspects. To research the issue in depth, we mostly used a qualitative approach to examine perceptions and to frame the brownfield issue. We partly applied frame analysis, a narrative approach and we also used research techniques such as document content analysis, and in-depth interviews with relevant stakeholders who are involved in the remediation of brownfields and their subsequent re-use $\left(\mathrm{N}_{=15}\right)$. We researched how stakeholders perceive and frame the problem and which solutions they prefer. Moreover, having made a comparison of the state of affairs between 2001 and 2012, we presented a deeper insight into the topic. We found quite a wide range of opinions toward the brownfields issue and its solutions. The main issues were related to people striving to find the identity of the city and the tension between the old and the new: looking for the direction of future development and the face of the city of Ostrava. We identified location, level of environmental degradation and social-economic conditions as the main factors that influence the brownfield issue.
\end{abstract}

Key words: Urban brownfields, Remediation, Cultural continuity, Demolition, Environmental change perception, Urban planning, Frame analysis.

Article Info: Manuscript Received: March 22, 2013; Revised: October 18, 2013; Accepted: November 11, 2013; Online: November $20,2013$.

\section{Introduction}

Currently, most municipalities and urban planners are facing many challenges about how to ensure sustainable development (Echenique at al. 2012; Keivani 2010). Post-communist urban planners have to cope especially with contradictory city development and pressures caused by multiple transformations from the former communist way of controlled urban planning to a new market-oriented environment. These contradictions are still manifesting in the urban, social and institutional structures of post-communist cities (Sýkora and Bouzarovski 2012).

Some examples of these key challenges include

\footnotetext{
* Corresponding author:

Address: Belidla 698/4a, Brno, 603 00, Czech Republic.

Telephone: +420 601383193

Email:arobrab@centrum.cz
}

how to keep the urban sprawl in the peripheral parts of the cities under control while protecting the historical centres, how to prevent social exclusion of minorities or socially disadvantaged groups and how to maintain the vast urban infrastructure (Suditu 2012). Other problems include the need for conservation of greenfield sites together/along with regeneration of devastated and usually abandoned sites commonly defined as brownfields (i.e. Alker et al. 2000; Dixon 2007; Williams and Dair 2007).

In this paper, we illustrated an urban transition process based on a description of a case study of the city of Ostrava, also known as the core of the Ostrava Agglomeration. The Ostrava Agglomeration has a rather polycentric character and is defined by intense commuting from the surrounding municipalities to centre for work, education and services. Population density and its structure have been changing over time (Figure 1). 


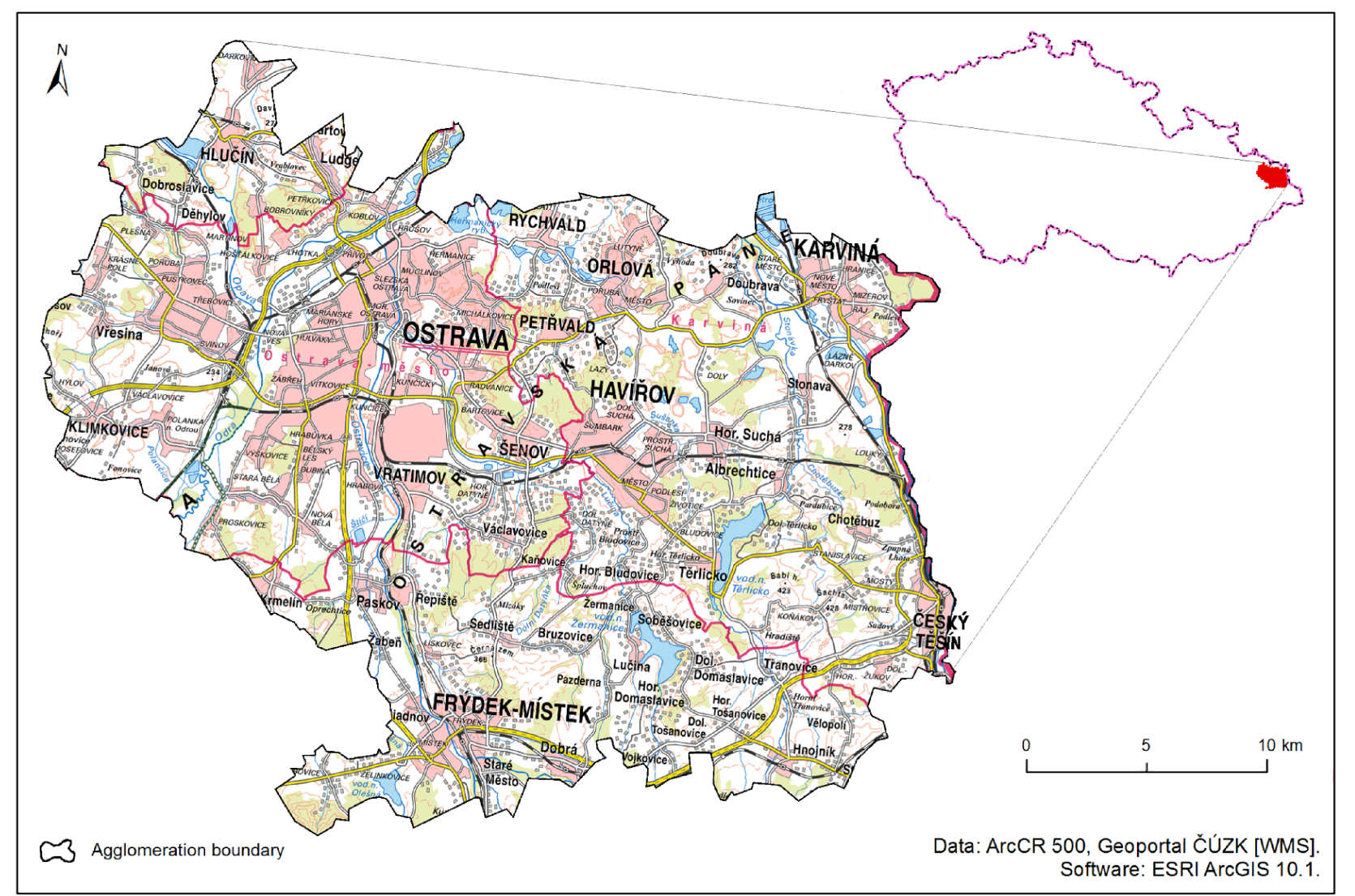

Figure 1. Ostrava Agglomeration

The city of Ostrava serves as the industrial, business and educational centre of the agglomeration. The core part of the city is delimited by Haviřov, Hlučín, Orlová, Bohumín, Karviná and Bílovec. Some nearby towns show a trend of independent development: for example, Frýdek-Místek serves as a popular place for immigration from Ostrava and has a strong industrial character and Opava functions as an important place of education thanks to its university (for more details see Hruška - Tvrdý, 2011).

The city of Ostrava and the surrounding towns have experienced both rapid industrial development and a process of urbanization since the second half of the nineteenth century. A relatively unknown preindustrial town has turned into a strategic industrial city within several decades due to its resources of black coal and its connection to heavy industry (Jiřík et al., 1993). However, after 1948, especially in the 1950 and 1960s, the communist regime radically changed its vision of industrial development. Nevertheless, the industrial role of Ostrava increased more than ever, as well as with the development of heavy industry, coke production, the chemical industry and machinery (Jiř́k et al., 1993).

We need to point out that the situation of postcommunist industrial cities differs greatly from the rest of Europe. Urbanization, industrial development and other processes did not took place under the rules of free markets controlled by democratic mechanisms and conditions set up by urban planning pro- cesses, but under the rules directed by the needs of a centrally planned economy. The main role of urban development was to fulfil the function of setting up and meeting the norms of coal mining and metal production. This characteristic of the city was expressed by the folk epithets "the steel heart of the republic", "the steel city" and "Black Ostrava" (Jiřík et al., 1993).

In the 1990s, just after the collapse of communist regime, a process of partial de-industrialization and structural changes emerged having serious economic and social consequences. This process has its disadvantages as it was implemented several decades behind other capitalist cities(Kuta, 2001; Charvát, 1992), while other post-communist cities such as Košice in the Slovak Republic, Miscolc in Hungary and Katowice in Poland have had already experienced it (see Popescu and Pătrăşcoiu 2012, Hruška-Tvrdý, 2011).

In order to illustrate this we mentioned some of the main socio-economic and demographic trends, from the 9os. In Ostrava Region, in 1994, the coal mining activity stopped while selected industries and the industrial production gradually decreased. If in $196159.9 \%$ of all employed people worked in the industrial sector, in $199143.7 \%$ and in 2001 the number had decreased to $26.8 \%$ (Hruška-Tvrdý, 2011; CSI, 2012). As a result, the unemployment rate continually rose. Thus, in 1997 it was of only $6.5 \%$, then it quickly increased to $16.5 \%$ between 2000-2002, had a peak in 2003 of $18.9 \%$, then it continually decreased to its 
current rate of $11.5 \%$ in 2011 (Ministry of Social Affairs, 2012). The population of Ostrava was in 1992 of 327413 inhabitants and then it had a decreasing trend, partly due decreasing birth rates but also due to out-migration. The current number of inhabitants (301942) closely corresponds to the year 1976 (300799 inhabitants, CSI, 2012).

In the main body of the paper, we paid special attention to the brownfields issue as one of the most important challenges of city transformation and redevelopment. We do not intent to give an exhaustive enumeration of all brownfields located in Ostrava. Conversely, we rather focus on depicting two cases in order to emphasize the key factors influencing their future use. To delineated the subject of the research, by reporting to specific types of brownfields: the industrial brownfields, located within the inner urban agglomeration. Their importance is underlined not only by the historical interconnection with the development of the city and community livelihoods, but also the existence of cultural heritage declared at a local or international level. In the past, the function of industrial zones was associated with a symbol of industrial development, but the closure of many of these industries made its iconic representation more difficult.

\section{The Brownfield Issue from an International Perspective}

Brownfields range on a diverse scale of sites. They do not only cover industrial elements, but also agricultural, military or residential examples. To avoid misunderstanding, many researchers have attempted to work out clear definitions of brownfields (i.e. Alker et al 2000; Alkin 2006; Loures, 2010). Definitions and conceptual frameworks were further developed within European research projects, such as CLARINET, CABERNET, RESCUE, BRINGUP and NICOLE.

Alker et al (200o, p. 49) point out that the definition should be understood, transparent and accepted by all stakeholders involved in the whole process of the brownfields solution. They focused on creating a more robust definition from a multidisciplinary perspective and came up with the following definition:

A brownfield site is any land or premises which has been previously used or developed and is not currently fully in use, although it may be partially occupied or utilized. It may also be vacant, derelict or contaminated. Therefore a brownfield site is not available for immediate use without intervention.

We found this definition highly useful, because it intends to include relevant factors, is widely comprehensible and covers all kind of brownfields related on their location. The definition also does not reject the fact that the areas may contain some environmentally -unfriendly characteristics.

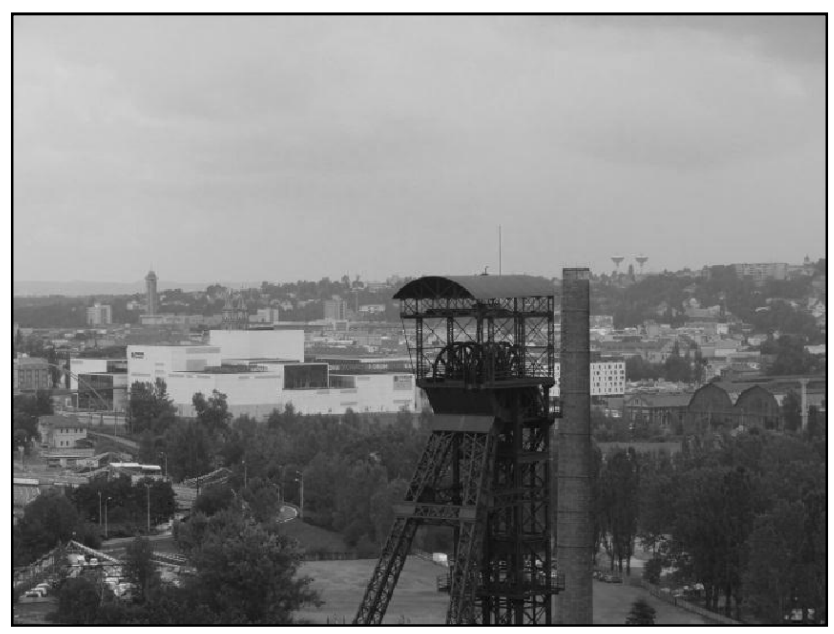

Photo 1. Ostrava Agglomeration

Other authors, such as Loures (2010), hold a wider and more community based approach and defined brownfields rather as "post-industrial landscapes". In questioning their potential, he called for more integrated and multifunctional longer-term solutions based on cultural, social, economic and ecological objectives. He stressed the need to return these landscapes to productive use, and to reintegrate them into the community. He also explored the dimension of industrial heritage and its role for the communities.

Human dimension and environmental justice were stressed by the authors, which emphasized the connection between the location of polluting activities and the living conditions of residents (Lee \& Mohai, 2012). They also explored the issue of residents' participation in the process of brownfield solutions.

Definitions from CEE (Central and Eastern Europe) countries are also valuable; for example Popescu \& Pătrăşcoiu (2012) referred to brownfields as a complex issue and set them on a symbolic scale between abandonment and redeveloped sites.

The connection between recovering brownfields and turning them back into a satisfactory state of remediation is also an important factor. This attitude stresses a partial re-greening process - the potential of greening industrial areas within city environments through creating parks, green corridors, green ways etc., and connecting the brownfield solution with environmental restoration and improvement of the urban environment (De Sousa 2003).

The authors focusing on sustainable development approaches point out that the mutual aspects of the phenomena should be taken into account, such as environmental, economic and social dimensions. They attempt to create a sustainability framework of assessment of brownfield redevelopment (Raco 2003; Dair and Williams 2007). 


\section{Brownfield Conceptual Framework within the Czech Environment}

In the Czech context, the term brownfield has been evolving and interpreted differently, depending on the context and stakeholders involved. Brownfields may be understand in a broader scope as "an environmental burden” caused by anthropogenic, mainly industrial, or mining activities, with negative effects on landscape functions and satisfying human needs (Havrlant, 1998).

Another interpretation, which is rather an illustrative distinction, is based on the evaluation of the level of contamination and redevelopment potential, according to the differentiation in the colour of the "field". While greenfields are evaluated as untouched by industrial activities, brownfields are interpreted as urban derelict areas. Although they have been influenced by anthropogenic activities, they still have the potential for redevelopment. The blackfields (see Havrlant, 1998) represent the most polluted, rather devastated areas with high-level contamination, posing serious environmental and health risks for the local residents or ecosystems. Undertaking redevelopment is a very exacting task (Tylčer, 1996).

As we mentioned above the collapse of the communist regime was accompanied by many structural changes in the whole of the Czech Republic. One of the key changes was the transfer of property from state to private through the process of privatization and restitution.

During the privatization process, the problem of previous devastation and pollution emerged on a large scale. The new owners were concerned about uncertain level of contamination, caused by the previous owners - the state companies. From this point of view, the origin of the contamination was not known or did not exist. Thus, the specific term "an old environmental burden" was created and then incorporated into legislative norms. (Tylová, 1996; Garband and Jackson, 2006).

The term old environmental burden relates to the ambiguity of the initiator of the contamination. It was strongly connected to two aspects of the problem: proving contamination along with determining responsibility for remedying the problems in the selected localities that contain an old environmental burden, along with the establishing solutions together with the financial transfer procedures. The National Property Fund (NPF) became responsible not only for organizing the privatization process, but also for the financial support of the old environmental burden agenda with the cooperation of the Ministry of Environment and the Ministry of Finance. The financial support for remedying this was designed via an ecological contract or by reducing the price of the purchase contract. Apart from this, selected state and regional organizations were incorporated into the process (Tylová, 1996; Svoboda, 1999; Garband and Jackson, 2006).
The definitions and the terms were been developed into their final form in the Government Resolution: The Solution of Old Ecological Burdens during Privatization, N. 810/1997 (Government Resolution, 1997, p. 3):

Old environmental burdens are caused by previous anthropogenic activities and constitute serious contamination of underground water, bedrock and buildings and disposal sites. Their existence represents a serious biological, physical, chemical threat to the environment and human health.

The meaning of the old environmental burden definition corresponds to the routine brownfields definition, but is more specific and focuses on the environmental and health risks. Paying attention to the term "brownfields", wehave noticed that the term had been used more often in the practice of land use planning or regional development. This is strongly connected with their potential social and economic benefits. For example, the state agency Czechinvest manages the web sites containing the list of brownfields that were offered to potential investors. In this context, Czechinvest (2008) defines brownfields as follows:

We define brownfields as property (estate, site, building) that is not sufficiently used, is unkempt and potentially contaminated. It is not possible to use them effectively without a regeneration process. It includes remains of industrial, agricultural, residential, military or other activities.

In order to sum up, using the term brownfields became general common practice. On the other hand, old environmental burdens refer to the specific kind of brownfields that contain environmental contamination and contain particular property relations. They have been defined within special legislation and their solutions were subject to a specific procedure.

Brownfields are recognized not only for their redevelopment potential, but they also contain some cultural and historical dimensions. These dimensions are related to representative architectural values such as industrial and educational heritage. (Matěj, 2001; Franger, 2001).

On the other hand, due to the new uncertain market environment and continuing structural changes in many sectors, brownfields solutions face a slowing down process in some cases, and even complete blockage due to a change of owners, bankruptcy, procedural, financial and other obstacles (see Garband and Jackson, 2006).

\section{Materials and Methods}

One of the major aims of our research was to identify which key factors may contribute to and influence 
the brownfields solution and show their manifestation in the redevelopment process of the particular case studies. another aim was to explore the culturalhistorical and environmental aspects of their reuse. We supplemented the research by analysing the perception and framing the issue with the relevant stakeholders and decision-makers involved in the remediation or the redevelopment process.

Based on the text analysis of information sources and taking into account the specific situation in Ostrava, we made a list of potential factors. Although these factors are listed individually, in practice they are usually interconnected and influence each other (Table 1).

To delineate the subject of the research, we pay attention to the specific types of urban brownfields: industrial brownfields, located within the inner urban structure. Their importance is underlined not only by their historical interconnection with the development of the city and community livelihoods, but also with the existence of cultural heritage.

In the empirical research process, we briefly describe the brownfield issue in Ostrava generally, but then we focus on specific case studies - namely Karolina and the Lower Area of Vítkovice. We describe the studies chronologically and insert selected statements to illustrate sociological insight into the cases. We used a research method based on content and frame analysis drawing on a study of official information sources, mainly the monthly magazine of the Ostrava Town Hall (available from 1997 to 2012, altogether 166 issues) to find out how the brownfield issue has been developed, framed and presented by the Ostrava municipality to the public.

In addition, we also conducted problem oriented interviews with selected stakeholders from different backgrounds to reveal the perception and evaluation of the process (overall $\mathrm{N}=15$ ). We conducted interviews in the years 2001 and 2012 proportionally (except NGO representatives - we conducted interviews with them only in 2002) and made a comparison.

We selected respondents in order to cover such issues as city planning, the cultural heritage, environmental aspects of brownfields aiming to get independent opinions from a bottom-up point of view. Respondents were divided into these categories:

Municipality representatives (Municipality, Department of City Planning, $\mathrm{N}=4$ )

Cultural experts (Culture, National Heritage Institute $\mathrm{N}=4$ )

Environmental experts (Environment, CzechEnvironmentalInspectorate, $\mathrm{N}=4$ )

GO representatives (Nongovernmental, NGO Vita, NGO Proměny, $\mathrm{N}=3$ )

Due to the separation in time (11 years), we were not able to conduct interviews with the same respondents and we are aware of a certain level of sub- jectivity and differences in their evidence. We tried to overcome this disadvantage by conducting complementary research with various on-line sources, blogs, and printed information sources, together with field observation. Field observation helped us to determine the evolution of a process over time. For example, Karolina, there was nothing but an empty plain, prepared for the process of remediation in 2001. In 2012, an open shopping mall, a residential area and an administrative centre covered the area. In the case of the Lower Area of Vitkovice, on the grounds of an empty factory in 2001, in 2012, several projects for remediation and reconstruction to serve a wide spectrum of use were implemented.

In doing so, we used the method of frame analysis for several reasons. First, the issue of brownfield remediation and redevelopment is very complex and needs to involve multiple actors with different backgrounds. Secondly, the frame analysis method seems to be the most appropriate in analysing different perceptions, attitudes and views towards a particular problem. Frame analysis is widely used in research into multi-dimensional topics such as climate change, sustainable development or other social and environmental challenges. The use of frames enables making sense of the complex reality of the world, and research tries to reveal their main frames and attitudes (see Galli, 2011).

Before the research process, we set up two main research questions concerning the future of brownfields:

1. How can the existence of industrial heritage influence the decision-making process concerning the future of brownfields?

We explored prevailing attitudes: the correspondence with cultural continuance, based on preservation of industrial objects / conversion and partial continuance / the choice of demolition discontinuity that effaces the traces of the previous industrial activities.

2. How can brownfield solutions contribute to environmental relief: Is their future use connected with environmental restoration?

We explored which forms of remediation prevailed: whether a repeated environmental burden for actual development needs / compromise strategy taking into account the society's needs and the needs of the land to regenerate / some forms of relief, based on the support of environmental restoration.

\section{The Case Study of the City of Ostrava: General Results}

First, we briefly describe the specifics of Ostrava and its main brownfields, and then we provide the results of the empirical research. 
Table 1. List of factors with a potential to influence the brownfields redevelopment in Ostrava

\begin{tabular}{|c|c|}
\hline Factor & Implication for the brownfield solution in the city of Ostrava \\
\hline $\begin{array}{l}\text { Owner/ } \\
\text { Acquirer }\end{array}$ & $\begin{array}{l}\text { Owners and their courage to invest in the affected locality play an important role. Several } \\
\text { owners, unclear property relations, and financial problems of owners could bring obstacles to a } \\
\text { successful and fast brownfield solution. The municipality can play an important role if they own } \\
\text { the site, or manifest an interest to buy a locality, keep it under control, and help with the } \\
\text { remediation and the preparation for future investments. Public-private partnerships could speed } \\
\text { up the solution. }\end{array}$ \\
\hline $\begin{array}{l}\text { Urban } \\
\text { Planning }\end{array}$ & $\begin{array}{l}\text { New urban plans have to adjust to the new conditions of industry conversion; improvements in } \\
\text { living and environmental standards and new trends in urban planning. The current Urban plan } \\
\text { of Ostrava suggests converting most of the former heavy industrial zones into light industry } \\
\text { zones, or multipurpose zones (i.e. residences, services, commercial, re-greening). }\end{array}$ \\
\hline $\begin{array}{l}\text { Location and } \\
\text { extent }\end{array}$ & $\begin{array}{l}\text { Location and area size strongly influence future brownfield use and financial costs. The closer to } \\
\text { the centre, the more attractive a site is for a potential investor and developers. The history of } \\
\text { Ostrava is connected with growth through the connection of surrounding villages. Currently, the } \\
\text { city is evaluated as quite a vast, discontinuous city. Unlike the inner centre, many site gaps are } \\
\text { located within Ostrava. In the past, these site gaps enabled many industrial zones to be } \\
\text { established and developed, but also to keep the existence of green sites. Remote brownfields } \\
\text { tend to suffer from abandonment, although the need for remediation may be high. }\end{array}$ \\
\hline $\begin{array}{l}\text { Environmental } \\
\text { factors }\end{array}$ & $\begin{array}{l}\text { These factors are important in evaluating risks to the environment (especially underground } \\
\text { waters and soil) and to health and setting up priorities for remediation. The remediation process } \\
\text { has to take into account the current financial and technical possibilities for "a societally } \\
\text { acceptable level of environmental and health risk". Moreover, the target level of remediation is } \\
\text { related to the intended future use of the locality and the choice of technology. }\end{array}$ \\
\hline $\begin{array}{l}\text { Social-economic } \\
\text { factors }\end{array}$ & $\begin{array}{l}\text { Cost-benefit analysis of remediation strongly influences the decision making process of potential } \\
\text { investors and developers. Economic factors should be connected with the improvement of social } \\
\text { conditions and employment opportunities. Inclusion of the brownfields agenda into the state } \\
\text { support program or EU donations means strong support for the remediation as well as the } \\
\text { redevelopment. }\end{array}$ \\
\hline $\begin{array}{l}\text { International } \\
\text { Experiences }\end{array}$ & $\begin{array}{l}\text { Based on international experiences, Ostrava can avoid former mistakes and draw inspiration } \\
\text { from good practice examples. Similar transformation was experienced in Glasgow, Bilbao, } \\
\text { Chicago, Detroit, Pittsburgh and other cities before. Ostrava faces the same problems as other } \\
\text { post-communist cities such as Miscols, Košice, Katowice (cities from the so-called Visegrad } \\
\text { countries). }\end{array}$ \\
\hline Stakeholders & $\begin{array}{l}\text { In the whole process, the public and private sectors, including various experts are involved. The } \\
\text { question is to what extent the public, NGOs, educational institutions, and residents are taken } \\
\text { into account in the decision-making process. }\end{array}$ \\
\hline Vision & $\begin{array}{l}\text { Vision helps to clarify the view on the future of the locality. It shows which direction of interests } \\
\text { prevail: the potential of economic redevelopment, natural potential, the industrial heritage } \\
\text { potential or an interconnection of them. }\end{array}$ \\
\hline Time & $\begin{array}{l}\text { The remediation and redevelopment process takes not only months, but years or even decades. } \\
\text { Although it is a time consuming process, it could enable a development or change of opinions } \\
\text { and attitudes to the brownfield issue in time. }\end{array}$ \\
\hline
\end{tabular}

Source: Authors' own work, based on available information sources

Ostrava is a discontinuous city organism, the result of historical development through the connection of surrounding villages. Moreover, four rivers flow across the city, forming green corridors. The specifics of Ostrava are the location of vast industrial zones that partly grow through the inner urban structure of the city of Ostrava, and partly create separate zones at its edges. Traditional coal, coke and chemical industrial zones are located along the Odra River (i.e. Lagoons brownfield on the map). The middle zone is wedged in the city (see the examples of Karolina, the Lower Area of Vítkovice and the DEZA former chemical factory), and the relatively separate peripheral zone, Kunčice, (eastern part of the city) consists of heavy industry which is still working. The former vast coal-mining zone extends from the middle of the city and continues through the city to the north-eastern part of the Ostrava Agglomeration (Figure 2).

The first systematic attempts to monitor brownfield sites showed that brownfields occupied around $15 \%$ of the total area of $21 \mathrm{~km}^{2}$ in 2001 (Ostrava Town Hall, 2001). The current area of around 79 brownfields makes up $8.9 \%$ of the city (Brownfields, 2012). Brownfields mostly include former coal mining areas, chemical and heavy industry equipment and waste sites. In the city around 20 former coal-mining sites are also located together with approximately 50 slag heaps, some of which still show thermal activity (State of the Ostrava Environment, 2006). 


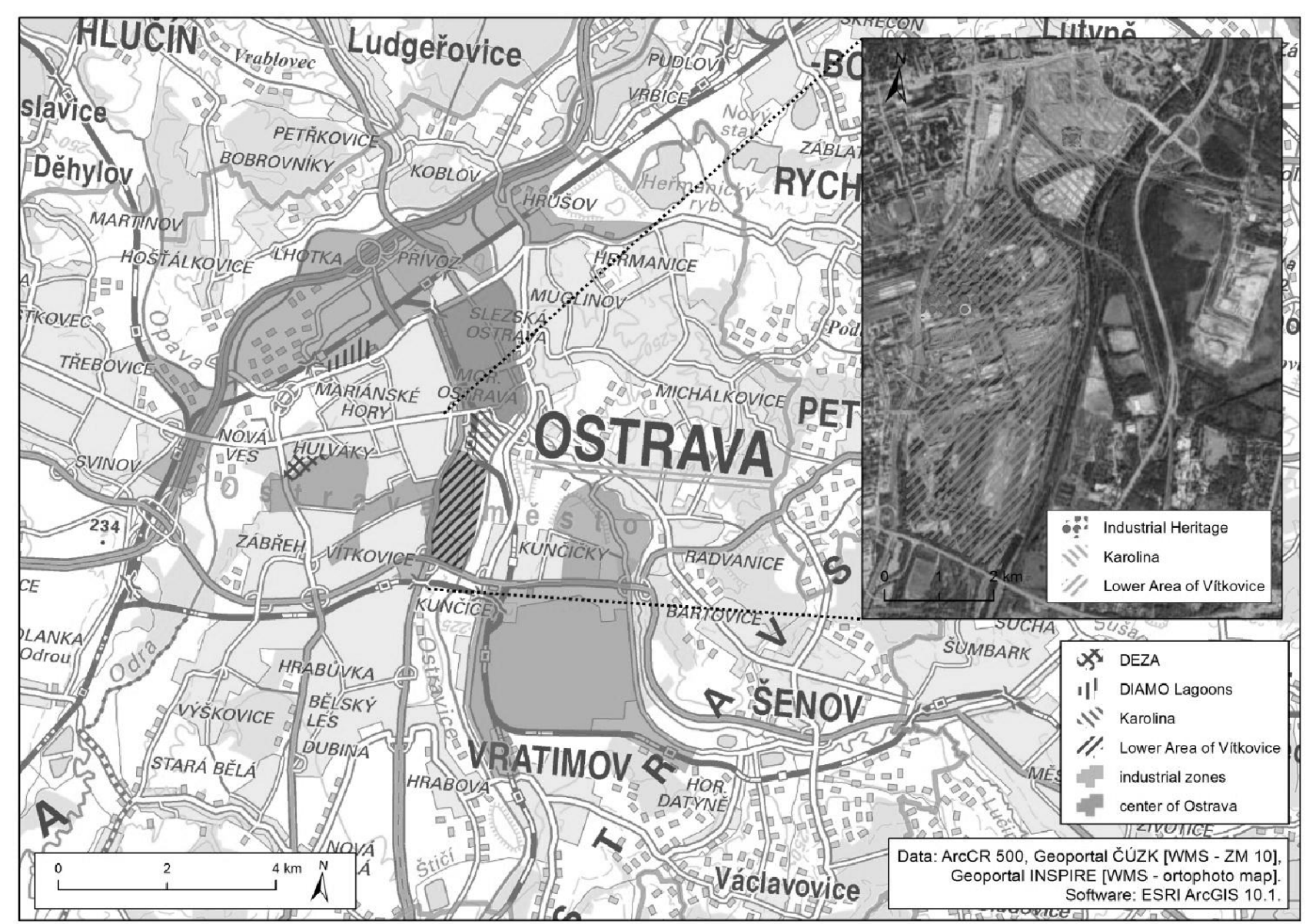

Figure 2. Location of the main industrial zones in Ostrava, the Karolina site and the VítkoviceDown Area, DEZA, Lagoons

Environmental problems are also related to social ones and they appeared mainly in the neglected areas located close to the industrial sites.

One of the most dangerous brownfields in terms of risk to the environment and health are the DEZA site and the Lagoons, both curried out from the end of the 19th Century. DEZA is a former chemical site and causes a threat to the underground drinking water reservoir. The Lagoons are filled with around 300,000 tons of chemical waste made by the former refinery and the surrounding chemical industries. The site is located nearby a housing estate and the river (State of the Ostrava Environment, 2006).

Based on a short excursion to the Ostrava brownfields, the question arises regarding how brownfields are perceived in Ostrava, especially in relation to the threat of contamination. What is the role of the owners, and which factors influence their future?

\section{Values of Ostrava city and attitudes to industrial sites}

Based on document and interview analysis, we identified the emergence of the need to find a new identity, based on a comparison of old and new. The dilemma of rejecting or evaluating an industrial part of the city's identity varies across the respondents: The city is affected by considerable growth in industry. Industrial items were surrounded by zones that made living impossible. Communist planners intended to demolish residences located close to industrial sites (Municipality, 2001).The sites have historical and cultural specificities. People do not want to live there - they perceive them as destroyed areas. The point is how to make these sites inhabitable as well as keeping their specificity (Culture, 2001). The strangeness of industrial sites is fascinating to some extent. (Nongovernmental, 2001).

\section{Perception of the Seriousness of Brownfields}

Text analysis and interviews show the process of developing perception and recognition of the scale of the problem. Over time, brownfields have been mapping and new solutions continually came up. The municipality recognizes the need to take control of selected brownfields. Owners are perceived as one of the key factors enabling or blocking the solution due to various factors, including property issues. (Table 2). The problem of brownfields is not taken seriously. After their closure or demolition, the gravity of the situation was detected. We underestimated the problem (Municipality, 2001) 
Table 2. Discussion over the future of industrial sites

\begin{tabular}{|c|c|}
\hline Kind of Solution & Perception and Discussion of the problem \\
\hline Demolition & $\begin{array}{l}\text { Remediation, demolition and following redevelopment is an energetically and } \\
\text { financially expensive process. From the psychological point of view, it does not consider } \\
\text { the need for continuity - the former industrial site is simply "left". It also poses the } \\
\text { question: how can the new composition fit with the current environment? On the other } \\
\text { hand, we cannot simply condemn the demolition solution. If the level of contamination } \\
\text { is so high and poses serious environmental and health risks and industrial objects are in } \\
\text { a dilapidated condition, then there is no way other than to agree to demolition solution. } \\
\text { The demolition solution may bring a new chance for a wide spectrum of new } \\
\text { redevelopment of the area. }\end{array}$ \\
\hline Conversion & $\begin{array}{l}\text { Reconstruction and following conversion into different functions is financially, } \\
\text { energetically and mentally expensive depending on its future use - light industry, } \\
\text { residential zone, cultural and others. The aim of the conversion is partially connected } \\
\text { with the conservation of industrial objects, while finding a new fulfillment. It poses a } \\
\text { challenge for "recycling" the area and buildings. This kind of solution partly preserves } \\
\text { the historical continuity of the place and supports creativity regarding how to manage it. }\end{array}$ \\
\hline Authenticity conservation & $\begin{array}{l}\text { Conservation of industrial objects could be less expensive, but is highly mentally } \\
\text { demanding. It contributes to the conservation of historical memory and the sense of } \\
\text { continuity. Although the industrial area has already lost its function, it still serves as an } \\
\text { identification point with the past. Industrial objects present a potential use for scientific, } \\
\text { research, cultural and educational activities: open-air museums, indoor museums, "last } \\
\text { working day" exhibition or, in extreme cases as "controlled ruins". }\end{array}$ \\
\hline $\begin{array}{l}\text { Repeated Environmental } \\
\text { Burden }\end{array}$ & $\begin{array}{l}\text { This form of reuse is based on the intensive form of land recycling. It consists of a high } \\
\text { level of rebuilding, usually for industrial, residential or commercial use. Once degraded } \\
\text { land is remediated and then repeatedly burdened. On the other hand, this form of } \\
\text { recycling the land is not so devastating and enables the original greenfields to be saved. }\end{array}$ \\
\hline $\begin{array}{l}\text { Integrated } \\
\text { Redevelopment }\end{array}$ & $\begin{array}{l}\text { The aim of this attitude is to achieve a balance between the economic development, the } \\
\text { needs of residents and the restoration of ecological processes in the area. This way } \\
\text { corresponds with the idea of sustainable development. }\end{array}$ \\
\hline $\begin{array}{l}\text { Environmental } \\
\text { Restoration }\end{array}$ & $\begin{array}{l}\text { The restoration attitude focuses on supporting the regeneration of natural processes, and } \\
\text { is partly based on natural experiments and partly on anthropogenic influence. It } \\
\text { supports the development of new forms of postindustrial landscapes. In extreme cases, it } \\
\text { corresponds with a so-called post-industrial form of wilderness. }\end{array}$ \\
\hline
\end{tabular}

The aim of the brownfield solution is to introduce them once again into the city organism (Municipality, 2001). We are preparing a map of contaminated sites in order to determine priorities for remediation. The municipality will act as an engine for the remediation of devastated sites, but will not take over the obligation of owners (Magazine Ostrava Town Hall, 2000).

\section{Environmental Restoration vs. Redevelopment, Cultural Continuity vs. Demolition Discontinuity}

We found a wide opinion spectrum among respondents. We identified a clash between ideal and reality, with a vast influence of economic factors. The sites within the city structure have been used for redevelopment, and industrial sites for continuous production use. Only in remote areas larger parts are allowed to enable re-greening, but with the risk of re- mediation. The question of continuing to keep the industrial heritage was complicated due to the push for redevelopment.

The course of development generally progressed from the old to the new Ostrava. Thanks to the experts who supported the industrial heritage in the 1990s, its preservation is continued. The local press states: We do not mind leaving it on its own. It is fine - it will grow again (Municipality, 2001). Production should come back to this site (Environment, 2001). The key factor that influences the destiny of industrial sites is the use. It does not matter what kind of use, whether recent or new. The important thing is the owner who keeps it and takes an interest in the site (Culture, 2012).

From the beginning, nobody perceived this part of history as a part of our presence. Instead, people wanted to get rid of these remains. Currently, local 
initiatives are growing, the issue is popularized and people are interested in industrial heritage and are investigating what was here before (Culture, 2012).

\section{Selected case studies: Comparison of Karoli- na and the Lower Area of Vítkovice}

To make the comparison more illustrative, we set up a table with selected key factors and trends to show some similarities and differences (Table 3 ).

A frame analysis of the Ostrava Town Hall magazine (from 1997 to 2012) shows continual interest in brownfields, informing the public about the present state of affairs, and establishing partnerships in various projects. Top priority was always given to Karolina. In the 1990s, when Karolina was about to be remediated, the headlines were framed as "Karolinawithout toxins" and "Karolina about to brighten up and become beautiful".

After the release of the development project, its importance was interpreted as "the Karolina project is of European and even world importance". On the other hand, the Lower area of Vítkovicewas treated as a "complicated" issue from the beginning. When a strong-minded new owner bought it in 2003, this resulted in several years of rethinking its future vision and setting up the issue of a change of framing in a more positive way.

Revealing the revitalization project of the Lower Area of Vítkovice (2009) was connected with the start of the preparation process of Ostrava city to enter the Capital of Culture 2015 competition. The process took place from a top-down and bottom-up approach and enabled participation of a wider spectrum of stakeholders including the public on the vision of Ostrava. Although Ostrava did not win the title Capital of Culture 2015, in the end, the two years of preparation contributed to the preparation of various projects, connecting people and rethinking the identity of Ostrava.

In 2012, a wider part of the industrial heritage in the Lower Area of Vitkovice was open to the public for excursions and cultural events, including the conversion of the gas-keeper into a multicultural hall.

The project's motto was "dedicated in the past to work, dedicated now to education and fun". Moreover, official city and regional promotion and tourist materials recognized the existence of industrial heritage in the city, including the Lower Area of Vítkovice. Interviews with respondents revealed a development in the perception of the problem, especially in the case of Vítkovice.

The Ministry of Culture manifested courage and despite the voices of local representatives, declared Vítkovice a national cultural monument (Culture, 2001). It is a heap of scrap. In the centre of the city ruins remain. It is an embarrassment for the city. I do not mind if it is located at the peripheral part of the city (Municipality, 2001).

The industrial heritage rescued itself thanks to getting a new chance - it got a vision of new fulfilment and continuance (Municipality, 2012). Vítkovice contains several levels: the uniqueness of individual parts; their arrangement of technology flows from coal to coke and iron. On a whole, it is a symbol of the city' continuity (Culture, 2012).

\section{Conclusion}

The Brownfield issue in Ostrava generated a large range of differences amongst respondents concerning perception, framing the issue and possible solutions. In the 1990s an initial exploration of the issue took place. Stakeholders learned to coexist with market transformation including the rise of brownfields. Firstly, the need to explore the scale of the problem including mapping the situation, and setting up procedures for remediation connected with the potential reuse within urban planning arose. During the remediation process, stakeholders looked for ways to put redevelopment projects into practice and the municipality gradually tried to get information and take control over the process of the selected localities. Due to the complexity of the problem, various cases experienced a different pace in remediation or the redevelopment process.

Concerning the brownfield' complex perception, we identified manifold frames: brownfields as an obstacle to development, demolition discontinuity versus cultural continuity, the opportunity for remediation and redevelopment, and exploration of the city's new identity simultaneously based on the past. Brownfields were framed step by step from the perception of a threat to a challenge for redevelopment or environmental restoration.

We also revealed which key factors influence the future of brownfields and pointed out that they differ from case to case. The first is location; if the sites are located within the wider city centre, then the pressure, interest and will for redevelopment is high. The second key factor is social-economic, including ensuring the financial support for remediation. A push for careful remediation prevails if there is a strong will for redevelopment. Environmental burden is naturally also a very important factor hampering redevelopment, but if is located in an attractive place and there is strong motivation for redevelopment, the remediation process is pushed through.

The municipality plays an important role through land use planning and active participation in the brownfield solution. International cooperation is supported through excursions, experience exchanges and consultancy. 
Table 3. Key factors influencing the future of Karolina and the Lower Area of Vítkovice

\begin{tabular}{|c|c|c|}
\hline Factor & Karolina & Lower Area of Vítkovice \\
\hline Start - end & $1842-1986$ & $1828-1998$ \\
\hline Extent of the area & Approximately 60 hectares. & Approximately 150 hectares. \\
\hline $\begin{array}{l}\text { Kind of } \\
\text { industrial } \\
\text { activities }\end{array}$ & $\begin{array}{l}\text { Coal mining, coke and chemical industry, } \\
\text { power plant, warehouses. }\end{array}$ & $\begin{array}{l}\text { Coal mining, coke and light and heavy } \\
\text { industry (steel works, iron agglomeration, } \\
\text { warehouses). }\end{array}$ \\
\hline Location & $\begin{array}{l}\text { Close to the city centre and a residential area, } \\
\text { bordered by the river Ostravice. }\end{array}$ & $\begin{array}{l}\text { Close to Karolina, bordered by the river } \\
\text { Ostravice, a residential area and other } \\
\text { industrial zones. }\end{array}$ \\
\hline $\begin{array}{l}\text { Environmental } \\
\text { factors }\end{array}$ & $\begin{array}{l}\text { Diverse soil and underground water } \\
\text { contamination - old environmental burden }\end{array}$ & $\begin{array}{l}\text { Diverse soil and underground water } \\
\text { contamination - old environmental burden. }\end{array}$ \\
\hline $\begin{array}{l}\text { Character of the } \\
\text { site, state of } \\
\text { remediation }\end{array}$ & $\begin{array}{l}\text { Demolition of the majority of industrial } \\
\text { objects in the 1980s. The locality went } \\
\text { through the process of active and careful } \\
\text { remediation (1993 - 2005). }\end{array}$ & $\begin{array}{l}\text { Continuing demolition of selected industrial } \\
\text { objects; remediation process started in } 1996 \\
\text { with preliminary research. Process is still } \\
\text { continuing. }\end{array}$ \\
\hline $\begin{array}{l}\text { Industrial } \\
\text { heritage }\end{array}$ & $\begin{array}{l}\text { Cultural monuments: three power station } \\
\text { halls consisting of three buildings, built in } \\
\text { industrial Art Nouveau style. }\end{array}$ & $\begin{array}{l}\text { National cultural monument (2002), European } \\
\text { heritage (2008): around } 50 \text { hectares shows the } \\
\text { whole technological flow starting with } \\
\text { extraction of coal and ending with steel } \\
\text { manufacturing: coal mine, coke plant, steel } \\
\text { work, gasometer, and pipelines. }\end{array}$ \\
\hline $\begin{array}{l}\text { Intended use in } \\
\text { Urban City Plan }\end{array}$ & $\begin{array}{l}\text { Enlargement of the city centre: offices, } \\
\text { shopping area, residential area, culture, green } \\
\text { places, park. }\end{array}$ & $\begin{array}{l}\text { Mixed use: technical open-air museum, culture, } \\
\text { offices, firms, education, residential area, } \\
\text { shopping area, green places, park, and light } \\
\text { industry. }\end{array}$ \\
\hline $\begin{array}{l}\text { The current state } \\
\text { of redevelopment }\end{array}$ & $\begin{array}{l}\text { Privatization in 1990s, several owners. } \\
\text { Architectonic competitions announced } \\
\text { several times (1987, 1989, 2000). In } 2006 \\
\text { municipality announced a developer } \\
\text { competition with the condition to ensure } \\
\text { financial sources enabling realization. In } 2008 \\
\text { construction started; in } 2012 \text { the first stage } \\
\text { opened- a large shopping area, residences, } \\
\text { offices, park. Process in motion. }\end{array}$ & $\begin{array}{l}2003 \text { process of privatization, one owner. In } \\
2009 \text { the private owner announced an } \\
\text { ambitious plan: education, science, culture, } \\
\text { residences, hotel, service, parks. In } 2007 \text { the } \\
\text { first excursions started (continual } \\
\text { reconstruction), } 2012 \text { reconstruction of gasoline } \\
\text { into the culture hall, summer music festival } \\
\text { took place in the area. Process in motion. }\end{array}$ \\
\hline Owner & $\begin{array}{l}\text { Several owners including municipality. After } \\
\text { remediation, the locality was sold to } \\
\text { developers. Industrial heritage has been } \\
\text { repaired thanks to public-private partnership } \\
\text { and EU funds. }\end{array}$ & $\begin{array}{l}\text { One strong private owner who founded a non- } \\
\text { governmental association and cooperates } \\
\text { through private-public partnership, drawing } \\
\text { on EU funds. }\end{array}$ \\
\hline $\begin{array}{l}\text { Framing of the } \\
\text { issue, the vision }\end{array}$ & $\begin{array}{l}\text { The municipality acted as an untiring } \\
\text { initiator of the solution. The vision of the city } \\
\text { representatives to build the new centre on the } \\
\text { open free space, described as a centre } \\
\text { enlargement. The main framing of the issue is } \\
\text { the hope to find a new identity, new vision, } \\
\text { and new potential. }\end{array}$ & $\begin{array}{l}\text { The frame of the issue has developed slowly. } \\
\text { The locality was treated as complicated, too } \\
\text { heterogeneous, the extent of conservation } \\
\text { seemed to be too large. In } 2009 \text { the private } \\
\text { owner released the project; the main frame is } \\
\text { connecting old and new: emphasizing the } \\
\text { cross-border importance of the area. }\end{array}$ \\
\hline $\begin{array}{l}\text { Perception of the } \\
\text { wider public }\end{array}$ & $\begin{array}{l}\text { Public perception differs. Some web blogs } \\
\text { mention the project of New Karolina as a } \\
\text { "wasted opportunity". Some civic initiatives } \\
\text { call it "New Fukushima" to discredit the } \\
\text { project. }\end{array}$ & $\begin{array}{l}\text { Large sociological research (2000) revealed that } \\
\text { a high proportion of inhabitants connect its } \\
\text { identity with the silhouette of industrial } \\
\text { heritage. The problem was widely discussed. }\end{array}$ \\
\hline $\begin{array}{l}\text { The scale of } \\
\text { demolition - } \\
\text { continuity }\end{array}$ & $\begin{array}{l}\text { Most of the industrial objects were } \\
\text { demolished; just two buildings act as a } \\
\text { reminder to past industrial activity. The } \\
\text { project of regeneration plans to have cultural, } \\
\text { open market and sport use. }\end{array}$ & $\begin{array}{l}\text { Opinions as to the level of preservation or } \\
\text { demolition of the objects have developed } \\
\text { through time. The final concept aims to bring } \\
\text { new life into the industrial object, combined } \\
\text { with conversion and partial demolition. }\end{array}$ \\
\hline $\begin{array}{l}\text { The scale of } \\
\text { environmental } \\
\text { restoration }\end{array}$ & $\begin{array}{l}\text { Almost the whole site has been rebuilt; a } \\
\text { green line along the river, small parks and } \\
\text { individual plantation of trees are intended. }\end{array}$ & $\begin{array}{l}\text { The site has been partly rebuilt, partly } \\
\text { conserved; a green line along the river and } \\
\text { street, vast parks and individual plantation of } \\
\text { trees are intended. }\end{array}$ \\
\hline Current Name & New Karolina & New Vítkovice \\
\hline
\end{tabular}

Source: Author's own work, based on information sources, interviews, field research 
Vision is also a significant element, but it has to be connected with financial support. From the point of view of public participation, the brownfield solution is mostly in expert hands, with some limited possibilities for participation.

With reference to the quantitative research of Novosák et al. (2013), they researched and statistically compared around 180 urban as well as rural brownfield sites in Ostrava and its surroundings and found that environmental burden and former functional use was an important barrier to brownfield redevelopment. They also pointed to spatial and location factors as important points that needed to be taken into account.

Focusing on answering the research questions concerning the future industrial heritage and the level of environmental restoration, we show a comparison of Karolina and the Lower Area of Vítkovice. New Karolina is mostly going in the direction of demolition discontinuity. The discussion over the issue was framed mostly about the dilemma of future rebuilding. Developers bought perfectly prepared, decontaminated land nearby the city centre. Karolina is an exceptional example of the quest to find a new identity, and new hope of economic development in the city of Ostrava. In the future, it will coexist with the historical centre. Wide public discussion over the excessive capacity, appearance and social and economic impact of the shopping mall on small business continues.

The Lower area of Vitkovice faces several years' delay in finding a solution and represents another example of brownfield change, with the disadvantage of a large area and a vast part of industrial heritage. The vision of its future shape is even more ambitious, but is not in a contrast between the old and new, but rather aims to incorporate the old into the new. Conversion is the main purpose of the project. The owner of Vítkovice has a strong reputation, and his life is connected with Ostrava city. Environmental restoration is taken into account in the project and plans to strengthen green areas and vast green parks.

It is evident that both areas of brownfield sites have experienced vast environmental restoration thanks to the end of heavy industrial activities. In the case of Karolina, pressure for rebuilding was stronger than in the Lower Area of Vítkovice. But, both areas of brownfield sites contain green corridors along the Ostravice River that create a wider connection within the green infrastructure of the urban plan of Ostrava. The Lower Area of Vítkovice counts on having several forest parks and enabling environmental restoration on a wider scale.

Ostrava is a city in motion from being an old, industrial, black city to becoming a multi-coloured, modern, technological, cultural, green, and educated city. In the cases of Karolina and the Lower Area of Vítkovice, it manifests all the dimensions and devel- opment tensions of post-communist cities based on an "old" and "new" dichotomy. With conservation of the industrial silhouette of Vítkovice, the city's industrial foundations shouldn't be forgotten.

Conclusions partly showed tensions between future development and the direction of the postcommunist and partly post-industrialist city of Ostrava. This corresponds with theoretical and empirical research dealing with the struggle of post-communist cities in Central and Eastern Europe (see Sýkora and Bouzarovski 2012, Hruška-Tvrdý 2011).

\section{Acknowledgments}

Authors acknowledge support from the pro-jects "CzechGlobe - Centre of Global Climate Change Impacts Studies", No. CZ.1.05/1.1.00/02.0073, "Partnership in Climate Research and Adaptation Strategies", No. CZ.1.07/2.4.00/31.0056, Challenges for Urban Agriculture in Europe No. LD 13033 and institutional support by RVO 67179843 .

\section{References}

Alker, S, Joy, V, Roberts, P \& Smith, N 200o,'The Definition of Brownfield', Journal of Environmental Planning and Management, vol. 43, no. 1, pp. 49-69.

CENIA 2012, National Inventorying of contaminated sites, www.kontaminace.cenia.cz.

Czech Statistical Institute 2011, Census of Ostrava, viewed on 1 October 2012,

www.czso.cz/x/krajedata.nsf/oblast2/sldbxt?opendocument\&uzemi=obce.

Dair, C \& Williams, K 2007; Sustainable land re-use: The influence of different stakeholders in achieving sustainable brownfield developments in England Location', Environment and Planning, vol. 38, no. 7, pp. 1345-1366.

De Sousa, CA 2003,'Turning brown $\neg$ fields into green space in the City of Toronto, Journal of Landscape and Urban Planning, vol 62, no. 4, pp. 181-198.

Dixon, T 2007,'The Property Development Indus-try and Sustainable Urban Brownfield. Regeneration in England: An Analysis of Case Studies in Thames Gateway and Greater Manchester', Urban Studies, vol. 44, no. 12, pp. 2379- 2400.

Echenique, MH, Hargreaves, AJ, Mitchell, G \& Namdeo, A 2012,' Growing Cities Sus-tainably', Journal of the American Planning Association, vol. 78, no. 2, pp. 121-137.

Fragner, B 2001,'Industrial Traces', Forum of Ar-chitecture and Civil Integeneering, vol. 9, no. 4, pp. 6-7.

Garband, Y \& Jackson, J 2006,' Central Europe’s Brownfields: Catalysing a Planning Response in the Czech Republic' in U Altrock (ed.), Spatial planning and urban development in the new EU member states: from adjustment to reinvention, Hampsire, Burlingen, Ashgate, pp. 271-287.

Gilla, E 2011, Frame Analysis in Environmental Conflicts, Stockholm: KTH - Royal Institute of Technology School of Industrial Engineering and Management, $\mathrm{PhD}$ Thesis. 
Government Resolution 1997, The Solution of Old Ecological Burdens During Privatization, N. 810/1997.

Havrlant, M 1998, Evaluation of Ecological bur-dens, University of Ostrava, Ostrava.

Hruška- Tvrdý, L et al. 2011, Industrial city in post-industrial society. Comparison, ACCENDO, Ostrava.

Jiřík et al. 1993, History of Ostrava, Ostrava, Sfinga.

Keivani, R 2010,'A review of the main challenges to urban sustainability', International Journal of Urban Sustainable Development, vol. 1, no. 1-2, pp. 5-16.

Kučová, V \& Matěj, M 2006, Industrial com-plexes in Ostra$v a$, National Trust Institute, Ostrav.

Kuta, V 2001, Development problems of Ostrava Agglomeration, Transport, Ostrava.

Lee, S \& Mohai, P 2012,'Environmental Justice Implications of Brownfield Redevelopment in the United States', Society and Natural Resources, vol. 25, no. 6, pp. 602-6o9.

Loures, L 2009,'(Re)-Developing Post-Industrial Landscapes: Applying Inverted Translational Research Coupled With The Case Study Research Method', City Futures in a Globalising World: An international conference on globalism and urban change, 4-6 June 2009, Madrid.

Matěj, $\mathrm{M}$ et al. 2007, Technical monuments in Ostrava, Statutory City of Ostrava, Ostrava.

Ministry of Social Affairs 2012, Mean unemployment rates, viewed on 1 October 2012,

www.portal.mpsv.cz/sz/stat/nz/casove.../prumer_mn_od -97_portal.xls.

Municipality of Ostrava 1980, Urban plan of Ostrava, Ostrava.

National Brownfields database 2008, Czechinvest, viewed on 1 September 2012, www.brownfieldy.cz.

New Karolina, viewed on 1 October 2012, www.nova-karolina.cz.

New Vítkovice, viewed on 1 October 2012, from: www.newvitkovice.cz.

Novosák, J, Hájek, O, Nekolová, J \& Bednář, P, 2013,'The Spatial Pattern of Brownfield and Characteristics of Redeveloped Sites in the Os-trava Metropolitan Area (the Czech Republic)', Moravian Geographical Report, vol. 21, no. 2, pp. 36-45.
Ostrava Town Hall Magazine (Monthly Magazine) Ostrava, Statutory City of Ostrava, vol. 1997-2012, Monthly Journal.

Popescu, G \& Pătrăşcoiu, R 2012,'Brownfield sites - between abandonment and redevelopment. Case study: Craiova city', Human Geographies - Journal of Studies and Research in Human Geography, vol. 6, issue 1, pp. 91-97.

Raco, M 2003; Assessing the discourses and practices of urban regeneration in a growing region', Geoforum, vol. 34, pp. 37-55

Sandra, A, Joy, V, Roberts, P \& Smith, N 200o,'The Definition of Brownfields', Journal of Environmental Planning and Management, vol. 43, no. 1, pp. 49-69.

State of the environment in Ostrava 2006, Statutory City of Ostrava, Ostrava.

Statutory City of Ostrava 1994, Urban plan of Ostrava, Ostrava, viewed on 1 September 2012.

Statutory City of Ostrava 2012, Brownfields in Os-trava City, viewed on 1 September 2012, www.dychamproostravu.cz.

Suditu, M 2012,'Urban Sprawl - the legal context and territorial practices', Human Geographies-Journal of Studies and Research in Human Geography, vol. 6, no. 1, pp. 73-77.

Svoboda, Z 1999, Quantification economic lost during brownfield remediation, Center of Charles University, Prague.

Sýkora, L \& Bouzarovski, S 2011,'Multiple Tran-formations: Conceptualising the Post-communist Urban Transition', Urban Studies, vol. 49, no. 1, pp. 43-6o.

Tylčer, J 1998, Development of remediation of old environmental burdens in the Czech Republic, The Brownfields Centre, Ostrava.

Tylová, E 1999,'Old environmental burdens', Waste, vol. 5, pp. 8-11.

Williams, K \& Dair, C 2007,'A framework for assessing the sustainability of brownfield develop-ments', Journal of Environmental Planning and Management, vol. 50, no. 1, pp. 23-40.

Zareba, A 2010,'A Multifunctional Mosaic of Green Spaces in the Context of the Lower Silesia Region (Southern Poland)', Problems of Sustainable Development, vol. 5, no 1, pp. 45-51. 